\title{
МІГРАЦІЙНА ПОЛІТИКА ЕС: ТЕНДЕНЦІЇ ФОРМУВАННЯ МІГРАЦІЙНИХ ПОТОКІВ ТА МЕХАНІЗМИ ВДОСКОНАЛЕННЯ
}

\section{EU MIGRATION POLICY: TRENDS IN THE FORMATION OF MIGRATION FLOWS AND IMPROVEMENT MECHANISMS}

\author{
Чернега Оксана Богданівна \\ доктор економічних наук, профресор, \\ Донецький національний університет економіки і торгівлі \\ імені Михайла Туган-Барановського \\ ORCID: https://orcid.org/0000-0002-5659-3808 \\ Яковенко Юрій Вячеславович \\ асистент, \\ Донецький національний університет економіки і торгівлі \\ імені Михайла Туган-Барановського \\ ORCID: https://orcid.org/0000-0003-1653-0834 \\ Chernega Oksana, Yakovenko Uyrii \\ Donetsk National University of Economics and Trade \\ named after Mykhailo Tugan-Baranovskyi
}

\begin{abstract}
Стаття присвячена актуальним питанням міграційної політики Європейського Союзу у контексті вдосконалення механізмів регулювання міграційних потоків. Мета статті полягає у встановленні тенденцій фрормування міграційних потоків від країн-донорів та країн проміжної дислокації до ЄС, визначенні основ міграційної політики ЄС та механізмів її вдосконалення. В процесі дослідження питання міграційної політики Європейського Союзу у контексті вдосконалення механізмів регулювання міграційних потоків було використано загальнонаукові методи наукового пізнання. Методи групування та порівняння використано під час дослідження міграційних маршрутів до ЄС. Табличний метод було використано під час узагальнення чисельності міграційних потоків до ЄС. Методи аналізу, синтезу та узагальнення використано під час визначення основних характеристик міграційних маршрутів. Методи індукції, конкретизації та абстрагування використано під час визначення сутності політики «міграційного щита». У статті було розглянуто основні фрактори міграційних процесів у світі. Узагальнено основні напрями імміграційної політики Європейського Союзу. Досліджено основні напрями (маршрути) міграційних потоків до Європейського Союзу. Проведено детальний аналіз інтенсивності міграційних потоків біженців та осіб без громадянства до Європейського Союзу у 2015-2019 роках. Визначено основні характеристики та особливості кожного з міграційних маршрутів до Європейського Союзу. Окреслено основні причини нерівномірного розподілу мігрантів між країнами-членами Європейського Союзу. Досліджено інтенсивність міграційних потоків біженців та осіб без громадянства до Європейського Союзу Східним сухопутним маршрутом у 2015-2019 роках. Окреслено необхідність співпраці України та Європейського Союзу в межах Східного сухопутного маршруту. Визначено та згруповано основні заходи Європейського Союзу під час міграційної кризи у 2015 році. Практично доведено ефективність тактики «міграційного щита», як нового міграційного інструменту Європейського Союзу під час міграційної кризи у 2015 році.

Ключові слова: міграція, міграційна політика, міграційний потік, міграційний щит, країна-донор, країна проміжної дислокації.

Статья посвящена актуальным вопросам миграционной политики Европейского Союза в контексте совершенствования механизмов регулирования миграционных потоков. Цель статьи заключается в установлении тенденций фрормирования миграционных потоков от стран-доноров и стран промежуточной дислокации в EC, определении основ миграционной политики ЕС и механизмов её совершенствования. В процессе исследования вопроса миграционной политики Европейского Союза в контексте совершенствования механизмов регулирования миграционных потоков были использованы общенаучные методы научного познания. Методы группировки и сравнения использованы при исследовании миграционных маршрутов в ЕС. Табличный ме-
\end{abstract}


тод был использован в ходе обобщения численности миграционных потоков в ЕС. Методы анализа, синтеза и обобщения использованы при определении основных характеристик миграционных маршрутов. Методы индукции, конкретизации и абстрагирования использованы при определении сущности политики «миграционного щита». В статье были рассмотрены основные факторы миграционных процессов в мире. Обобщены основные направления иммиграционной политики Европейского Союза. Исследованы основные направления (маршруты) миграционных потоков в Европейский Союз. Проведен детальный анализ интенсивности миграционных потоков беженцев и лиц без гражданства в Европейский Союз в 2015-2019 годах. Определены основные характеристики и особенности каждого из миграционных маршрутов в Европейский Союз. Определены основные причины неравномерного распределения мигрантов между странами-членами Европейского Союза. Исследована интенсивность миграционных потоков беженцев и лиц без гражданства в Европейский Союз Восточным сухопутным маршрутом в 2015-2019 годах. Определена необходимость сотрудничества Украины и Европейского Союза в рамках Восточного сухопутного маршрута. Определены и сгруппированы основные мероприятия Европейского Союза во время миграционного кризиса в 2015 году. Практически доказано эфрфективность тактики «миграционного щита», как нового миграционного инструмента Европейского Союза во время миграционного кризиса в 2015 году.

Ключевые слова: миграция, миграционная политика, миграционный поток, миграционный щит, странадонор, страна промежуточной дислокации.

The article is devoted to topical issues of migration policy of the European Union in the context of improving the mechanisms for regulating migration flows. The purpose of the article is to identify trends in the formation of migration flows from donor countries and countries of intermediate location to the EU, to determine the foundations of EU migration policy and mechanisms for its improvement. In the process of research the issue of migration policy of the European Union in the context of improving the mechanisms for regulating migration flows, general scientific methods of scientific knowledge are used. In the process of research migration routes to the EU are used grouping and comparison methods. The tabular method is used to summarize the number of migration flows to the EU. Methods of analysis, synthesis and generalization are used in determining the main characteristics of migration routes. The methods of induction, concretization and abstraction are used in determining the essence of the "migration shield" policy. The main factors of migration processes in the world is researched in the article. The main directions of the immigration policy of the European Union are generalized. The main directions (routes) of migration flows to the European Union are researched. A detailed analysis of the intensity of migration refugees flows and stateless persons to the European Union in 2015-2019 is conducted. The main characteristics and features of all migration routes to the European Union are identified. The main reasons for the migrants inequality between the member states of the European Union are outlined. The intensity of migration refugees flows and stateless persons to the European Union by the Eastern land route in 2015-2019 is studied. The need for cooperation between Ukraine and the European Union within the Eastern Land Route is outlined. The main measures of the European Union during the migration crisis in 2015 have been identified and grouped. The effectiveness of the "migration shield" tactics as a new migration tool of the European Union during the migration crisis in 2015 has been practically proved.

Keywords: migration, migration policy, migration flow, migration shield, donor country, country of intermediate location.

Постановка проблеми. Одним з історичних фракторів розвитку людства є міграція. Саме переміщення населення в межах країни, регіону, континенту сприяли фрормуванню торговельно-економічних відносин у світі. Історично сорормувалося декілька центрів міграційного тяжіння, серед яких особливе місце посідає Європейський регіон. Згідно з даними Євростату чисельність людей, які мігрували та проживають у державах-членах $€ С$ з громадянством країни, що не $€$ членом $€ C$, на 1 січня 2019 року становила 21,8 млн. осіб, що становить $4,9 \%$ від загальної чисельності населення країн $€ C$ [1].

Міграційна політика $€ С$ направлена на регулювання усіх видів міграції населення, у тому числі і комплекс дій щодо біженців та осіб без громадянства. Проте, сучасні міграційні виклики, в першу чергу, міграційна криза ЄС у 2015 році, визначили необхідність якісного вдосконалення затверджених положень міграційної політики $€ C$. Особливої уваги потребують такі напрями міграційної політики ЄС як забезпечення контролю та процедури легалізації осіб без громадянства, своєчасне вживання превентивних заходів щодо зменшення негативного впливу зон міграційного напруження, розроблення механізму мінімізації негативного впливу від міграції біженців, осіб без громадянства та інших мігрантів під час глобальних викликів людства, зокрема пандемій, забезпечення механізму асиміляції біженців та осіб без громадянства, які перебувають на території $€ \mathrm{C}$, вдосконалення механізмів співпраці між $Є C$, регіонами проміжної дислокації та регіонами-центрами формування міграційних потоків, забезпечення дієвої координації зусиль між країнами ЄС щодо провадження спільної міграційної політики. 
Аналіз останніх досліджень і публікацій. Питанню дослідження міграційної політики Європейського Союзу у контексті вдосконалення механізмів регулювання міграційних потоків присвячено праці багатьох дослідників. Ніколо Конті, Данило Ді Мауро та Вінченцо Мемолі [2] акцентували свою увагу на проблемах державної підтримки інтегрованої імміграційної політики ЄС. На основі ряду міграційних моделей дослідники визначили ступінь впливу імміграції в $€ С$ на соціальні настрої громадян та здатність провадити спільну імміграційну політику між країнами-членами ЄС. Траєкторію руху ЄС щодо інтеграції мігрантів приблизно за 20 років свого існування було досліджено П'єром Жоржем Ван Воллегемом [3]. Дослідником було проаналізовано основні міграційні політики ЄС в контексті спільних політик Співтовариства. Було визначено успішність Фонду притулку, міграції та інтеграції, діяльність якого у період з 2021 по 2027 роки дозволить $€ C$ отримати сильнішу процедурну владу над усією схемою фрінансування міграційних видатків Співтовариства.

Жоао Естевенс [4] акцентував увагу на взаємозв'язку між міграцією та безпекою в $€ C$ шляхом оцінки стратегій національної безпеки та оборони держав-членів, а також ЄСВС 2016 року в період міграційної кризи, яка сьогодні $€$ однією $з$ найважливіших геополітичних проблем у ЄС. Дослідником було визначено, що еміграційні вектори до ЄС найбільше залежать від двох критичних невизначеностей: революцій, політичної та соціальної нестабільності в Північній Асриці і Близькому Сході, а також від майбутнього розвитку $Є$.

Дослідник Шубхам Поддар [5] вивчав позитивні та негативні наслідки від міграції біженців до ЄС. Особливу увагу дослідник приділив питанням економічних викликів, а також можливостей, пов'язаних з європейською кризою біженців, та потенціалу перетворення цієї гуманітарної катастрофри у сприятливу ситуацію для держав-членів ЄС. Дослідником було визначено, що криза біженців служить порятунком для багатьох європейських держав, оскільки надає їм можливість приймати нових членів до своєї робочої сили та забезпечувати постійне економічне зростання в майбутньому. Дослідник пропонує запровадити спільну платформу $€ C$, орієнтовану на біженців, яка відповідатиме за управління, фрінансування та контроль над притоком біженців централізовано та ефективно.

Виділення не вирішених раніше частин загальної проблеми. Не зважаючи на наяв- ність багатьох досліджень міграційної політики $€ С$ у контексті регулювання нелегальної міграції та враховуючи вплив фракторів економічного, політичного, військового характеру, а також фрорс мажорних обставин (пандемія), існує нагальна потреба подальшого вивчення проблеми нелегальної міграції біженців та осіб без громадянства до ЄС задля пошуку комплексу короткострокових та довгострокових заходів міграційного регулювання цих потоків.

Формулювання цілей статті (постановка завдання). Мета статті полягає у визначенні основ міграційної політики $€ С$, тенденцій фрормування міграційних потоків та механізмів ії вдосконалення. Основне завдання полягає у визначені заходів міграційної політики $€ C$, необхідних для регулювання і поступового зменшення чисельності нелегальних міграційних потоків біженців до ЄС.

Виклад основного матеріалу дослідження. Міграція населення $€$ об'єктивним процесом, що набуває свого розвитку під впливом багатьох фракторів. Впродовж всього історичного розвитку людства основними рушійними силами фрормування міграційних потоків у світі були і $€$ фрактори економічного (можливість якісного збільшення особистого прибутку; розширення особистого споживчого кошику; якісна самореалізація мігранта, як висококваліфікованого фрахівця; наявність широкої пропозиції вакансій на ринку праці у країні-реципієнті з більш конкурентним рівнем заробітних плат ніж у країні-донорі; наявність більш комфортних умов праці; великий рівень безробіття у країні-донорі), військово-політичного (військові дії; політична нестабільність; особливість політичного устрою в країні; громадянські конфолікти та війни; анексії територій); соціально-релігійного; інтеграційного (орормування міждержавних інтеграційних об'єднань, в яких є країни-лідери (реципієнти) та країни-аутсайдери (донори); територіальна близькість країни-донора та країни-реципієнта; явища глобалізації та інтернаціоналізації; укладання договорів щодо безвізового режиму) характеру.

Незважаючи на різноманітний економічний потенціал країн-членів $Є С$ вони фрормують єдине міжнародне інтеграційне об'єднання, яке $€$ економічно, політично і соціально потужним. Як наслідок, країни-члени ЄС є країнами-реципієнтами для міжнародного міграційного руху населення. Для есрективного регулювання міграційних потоків населення, які прибувають до країн-членів ЄС у межах Співтовариства, реалізується комплекс різноманітних політик і 
стратегій, серед яких пріоритетне місце належить саме міграційній політиці.

Міграційна політика складається із трьох основних елементів: еміграційного, імміграційного та інтеграційного, в межах яких фрормулюють окремі цілі, срормують інструменти та основні моделі. Відповідно до чинних нормативно-правових актів та міграційної політики ЄС, основними напрямами імміграційної політики $€ \subset \in$ :

- зменшення стимулів для нелегальної імміграції;

- управління кордонами - порятунок життя та охорона зовнішніх кордонів;

- розробка посиленої спільної політики надання притулку;

- встановлення нової політики щодо регулярної імміграції, модернізація та перегляд системи «блакитної картки»;

- встановлення нових пріоритетів інтеграційної політики та оптимізація переваг міграційної політики для зацікавлених осіб та країн їх походження.

Одним 3 найбільших викликів для усієї міграційної системи ЄС $€$ проблема значного зростання чисельності біженців та нелегальної імміграції. Згідно з статистичними даними у 2019 році на кордонах Європейського Союзу було виявлено майже 142 тис. незаконних перетинів кордону, порівняно 3 найнижчою чисельністю, що була зафріксована у 2013 році (107 тис. осіб) [6].

Критичний період зростання незаконних перетинів кордону $€ C$ було засріксовано у 2015 році (пік європейської міграційної кризи) під час якого було виявлено понад 1,8 мільйонів незаконних перетинів кордону [6]. Усі міграційні потоки біженців та нелегальних мігрантів доцільно розділити за чотирма напрямами:

- Східносередземноморський маршрут (Eastern Mediterranean route);

- Західносередземноморський маршрут (Western Mediterranean route);

- Західноафрриканський маршрут (Western African route);

- Центральносередземноморський маршрут (Central Mediterranean route).

Узагальнена характеристика щодо країн фрормування міграційних потоків та країнреципієнтів у межах $Є С$ наведено в таблиці 1.

Таким чином, основні потоки нелегальної міграції, біженців та осіб без громадянства прямують до $€ \subset$ з 3 країн Близького Сходу та Асррики. Для зменшення інтенсивності міграційних потоків за цими маршрутами $Є C$ запровадив комплекс заходів, що загалом передбачають посилену фрінансову підтримку країн проміжної дислокації для підвищення їх потужностей щодо стримування інтенсивних нелегальних міграційних переміщень (застосування тактики «міграційного щита»); фрінансування громад в країнах проміжної дислокації для мінімізації соціальної напруженості і компенсації збитків від неконтрольованих міграційних потоків; посилення прикордонних регіонів $€$; проведення спільних навчань для прикордонних інституцій між ЄС та країнами проміжної дислокації.

Застосування комплексних практичних заходів щодо зменшення інтенсивності неконтрольованих міграційних потоків до ЄС, починаючи з 2015 року принесло успішні підсумки, що підтверджуються офріційними статистичними даними. Чисельність міграційних потоків біженців та осіб без громадянства до ЄС у 2015-2019 роках відповідно до міграційних каналів наведено у таблиці 2.

Тобто у 2019 році, порівняно 3 2015, за двома маршрутами спостерігається зменшення інтенсивності міграції біженців та осіб без громадянства до ЄС. Суттєве скорочення обсягів міграції за Східносередземноморським маршрутом вдалося досягти завдяки співпраці між ЄС та Туреччиною. Загалом, було розроблено між Туреччиною та $€ C$ спільний механізм всебічного задоволення потреб біженців з Сирії (Організація ЄС для біженців у Туреччині). Починаючи 32015 року $€ C$ витратив на програму підтримки біженців у Туреччині 6 млрд. євро. Проте застосування цього інструменту можливо лише у середньостроковій перспективі (10-15 років), оскільки комплексне вирішення цієї проблеми стане можливим лише після припинення військових дій у Сирії та стабілізації її економічного становища. Окрім того реалізація цієї програми $€ C$ неможлива без кооперації з Туреччиною, політичний курс якої (посилення диктатури, порушення свободи слова та базових прав людини) суперечить базовим цінностям Співтовариства.

Міграційні потоки Західносередземноморського маршруту мали тенденцію до зростання з 2015 по 2018 роки. Після укладання ряду домовленостей між $Є С$ та Марокко, посилення останньою заходів міграційного контролю у кооперації з Європейським агентством прикордонної та берегової охорони $€ С$ вдалося досягти скорочення чисельності міграційних потоків біженців та осіб без громадянства.

Найбільше занепокоєння у ЄС викликає зростання чисельності міграційних пото- 
Таблиця 1

Узагальнена характеристика щодо країн формування міграційних потоків та країн-реципієнтів у межах ЄС

\begin{tabular}{|c|c|c|c|c|}
\hline $\begin{array}{l}\text { № } \\
\text { 3/ח }\end{array}$ & \begin{tabular}{|c} 
Країни \\
формування \\
міграційного \\
потоку
\end{tabular} & $\begin{array}{c}\text { Країни- } \\
\text { реципієнти }\end{array}$ & Характеристика маршруту & $\begin{array}{l}\text { Інструмент } \\
\text { регулювання }\end{array}$ \\
\hline 1 & 2 & 3 & 4 & 5 \\
\hline \multicolumn{5}{|c|}{ Східносередземноморський маршрут } \\
\hline 1 & $\begin{array}{c}\text { Сирійська } \\
\text { Арабська } \\
\text { Республіка, } \\
\text { Ірак, } \\
\text { Асрганістан }\end{array}$ & $\begin{array}{c}\text { Греція, } \\
\text { Кіпр, } \\
\text { Болгарія }\end{array}$ & $\begin{array}{l}\text { Міграційний потік виник в наслідок } \\
\text { військових дій у Сирії (активні дії } 3 \\
2015 \text { року), Іраку (з } 2003 \text { року) та } \\
\text { Асрганістані (з } 2001 \text { року). }\end{array}$ & $\begin{array}{l}\text { Посилене фрінансування } \\
\text { прикордонного та } \\
\text { приморського контролю } \\
\text { зокрема з боку Греції; } \\
\text { Фінансова співпраця з } \\
\text { Туреччиною як «мігра- } \\
\text { ційного щита» для неле- } \\
\text { гальної міграції до ЄС; } \\
\text { Створення Організації } \\
\text { ЄС для біженців, що діє } \\
\text { на території Туреччини } \\
\end{array}$ \\
\hline \multicolumn{5}{|c|}{ Західносередземноморський маршрут } \\
\hline 2 & $\begin{array}{l}\text { Марокко, } \\
\text { Алжир }\end{array}$ & Іспанія & $\begin{array}{l}\text { Нерегулярні прибуття до Іспанії як } \\
\text { через Середземне море до мате- } \\
\text { рикової частини, так суходолом до } \\
\text { іспанських анклавів Сеута та Мелі- } \\
\text { лья в Північній Афрриці. } \\
\text { Маршрут виник в наслідок дифе-- } \\
\text { ренціації між Іспанією, як економічно } \\
\text { потужної країни, з більш конку- } \\
\text { рентними заробітними платами та } \\
\text { іншими афрриканськими країнами, } \\
\text { що є менш економічно потужними } \\
\end{array}$ & $\begin{array}{l}\text { Посилення зусиль } \\
\text { Марокко щодо боротьби } \\
\text { з нелегальною } \\
\text { міграцією; співпраця між } \\
\text { Марокко, Іспанією та ЄС; } \\
\text { Посилення контролю за } \\
\text { кордонами зі сторони } \\
\text { Іспанії, Алжиру та } \\
\text { Марокко }\end{array}$ \\
\hline \multicolumn{5}{|c|}{ Західноафрриканський маршрут } \\
\hline 3 & $\begin{array}{c}\text { Марокко, } \\
\text { Західна } \\
\text { Сахара, } \\
\text { Мавританія, } \\
\text { Сенегал, } \\
\text { Гамбія, } \\
\text { Туніс }\end{array}$ & $\begin{array}{c}\text { Іспанія } \\
\text { (Канарські } \\
\text { острови) }\end{array}$ & $\begin{array}{l}\text { Мігранти вирушають у небез- } \\
\text { печні подорожі вздовж узбережжя } \\
\text { Західної Афррики, щоб дістатися до } \\
\text { Канарських островів. } \\
\text { Маршрут виник в наслідок дифе-- } \\
\text { ренціації між Іспанією, як економічно } \\
\text { потужної країни, з більш конку-- } \\
\text { рентними заробітними платами та } \\
\text { іншими афрриканськими країнами, } \\
\text { що є менш економічно потужними }\end{array}$ & $\begin{array}{l}\text { Ухвалення програми } \\
\text { «Партнерство в країнах } \\
\text { транзиту» між ЄС та } \\
\text { країнами Афррики; } \\
\text { Формування } \\
\text { Надзвичайного } \\
\text { цільового фонду ЄС для } \\
\text { країн Афррики (ЕUTF для } \\
\text { Афррики) }\end{array}$ \\
\hline \multicolumn{5}{|c|}{ Центральносередземноморський маршрут } \\
\hline 4 & $\begin{array}{l}\text { Лівія, } \\
\text { Алжир }\end{array}$ & $\begin{array}{l}\text { Італія, } \\
\text { Мальта }\end{array}$ & $\begin{array}{l}\text { Міграційний маршрут виник в наслідок } \\
\text { подолання наслідків військових дій у } \\
\text { Лівії, історичного аспекту (колонізації). } \\
\text { Мігранти вирушають у довгі, небез- } \\
\text { печні подорожі з Північної Афррики, } \\
\text { щоб перетнути Середземне море } \\
\text { і дістатися до Європи. Вони про- } \\
\text { їжджають транзитом через Лівію на } \\
\text { шляху до Європи. Це сприяло роз- } \\
\text { витку мереж контрабанди та торгівлі } \\
\text { людьми в Лівії. } \\
\text { Маршрут виник в наслідок позиціо- } \\
\text { нування Італії та Мальти, як еконо- } \\
\text { мічно потужних країн, з більш конку- } \\
\text { рентними заробітними платами та } \\
\text { купівельноспроможним населенням }\end{array}$ & $\begin{array}{l}\text { 3більшення підтримки } \\
\text { зі сторони ЄС лівійської } \\
\text { берегової охорони, } \\
\text { гуманних умов при- } \\
\text { йому та добровільного } \\
\text { повернення до країн } \\
\text { походження мігрантів, що } \\
\text { опинились у лівійській } \\
\text { місцевості; } \\
\text { Спільні навчання берего- } \\
\text { вої охорони ЄС та Лівії; } \\
\text { Підтримання програм доб- } \\
\text { ровільного повернення; } \\
\text { Підтримка ЄС місцевих } \\
\text { громад в Лівії }\end{array}$ \\
\hline
\end{tabular}

Джерело: складено автором за даними [7; 8; 9] 
Таблиця 2

Інтенсивність міграційних потоків біженців та осіб без громадянства до ЄС у 2015-2019 роках

\begin{tabular}{|c|c|c|c|c|c|c|c|}
\hline \multirow{2}{*}{$\begin{array}{l}\text { № } \\
3 / \Pi\end{array}$} & \multirow[b]{2}{*}{ Назва маршруту } & \multicolumn{5}{|c|}{ Чисельність мігрантів, тис. осіб } & \multirow{2}{*}{$\begin{array}{c}\% \\
\text { співвідношення } \\
2019 \text { до } 2015\end{array}$} \\
\hline & & 2015 & 2016 & 2017 & 2018 & 2019 & \\
\hline 1 & $\begin{array}{l}\text { Східносередземноморський } \\
\text { маршрут }\end{array}$ & 885,4 & 171,7 & 42,3 & 55,9 & 82 & $-90,7$ \\
\hline 2 & $\begin{array}{l}\text { Західносередземноморський } \\
\text { маршрут }\end{array}$ & 7 & 10,8 & 37 & 56,8 & 24 & 242,8 \\
\hline 3 & Західноафриканський маршрут & 0,8 & 0,6 & 0,4 & 1,5 & 2,5 & 212,5 \\
\hline 4 & $\begin{array}{l}\text { Центральносередземноморський } \\
\text { маршрут }\end{array}$ & 153,9 & 170,9 & 118,9 & 23,3 & 14 & $-90,9$ \\
\hline
\end{tabular}

Джерело: складено автором за даними [7; 8; 9; 10; 11; 12; 13; 14; 15]

ків біженців та осіб без громадянства через Західноафрриканський маршрут. Канарські острови, які $€$ кінцевою метою прибуття для мігрантів з Афррики, зважаючи на географрічне розташування, $€$ складною ділянкою для комплексного контролю та стримування міграції. Різке зростання міграційних потоків через цей маршрут у 2019 та 2020 роках частково зумовлено протиепідеміологічними заходами щодо запобігання поширенню COVID-19, запровадженими багатьма афрриканськими країнами, які призвели до скорочення офріційних пасажироперевезень між ЄС та країнами Афррики, створили додаткові перешкоди для переміщення традиційними міграційними шляхами та погіршили соціально-економічні умови життя в багатьох країнах-донорах. Окрім того, нелегальні мігранти обирають цей напрям міграції також в наслідок покращення управління міграційними процесами та прикордонного контролю в Марокко.

Успішною $€$ міграційна політика $€ С$, запроваджена для скорочення неконтрольованих міграційних потоків через Центральносередземноморський маршрут. Серед основних заходів, запроваджених ЄС для скорочення міграції за цим маршрутом варто виокремити такі: збільшення підтримки лівійської берегової охорони, у тому числі і фрінансової; затвердження 5 нових міграційних програм пов'язаних з міграцією в Північній Афрриці, на загальну суму 61,5 млн. євро, які направлені на захист та допомогу біженцям, найбільш вразливим верствам населення (мігрантам), поліпшення умов життя та економічної стабільності лівійців (фрінансова підтримка регіонів, що найбільше відчувають наслідки транзитної міграції); створення Надзвичайного цільового фронду $Є С$ для країн Афррики 3 загальним бюджетом 4,5 млрд. євро; проведення спільних навчань берегової охорони
Лівії та ЄС; фрінансова підтримка приймальних центрів; запровадження програм добровільного повернення мігрантів (для мігрантів, які опинилися в Лівії, проте не є її громадянами). Доцільно також врахувати той фракт, що Лівія починаючи з 2011 року намагається подолати наслідки громадянської війни. І допоки не відбудеться повна стабілізація економіки та її зростання, чисельність мігрантів саме з Лівії буде також зростати.

Одним 3 найбільш важливих напрямів міграційної політики ЄС є успішне залучення легальних трудових мігрантів, для збереження темпів розвитку економіки Співтовариства. Так, згідно з оцінками МОП, у 2020 році в ЄС працює 33 мільйони трудових мігрантів, що становлять 17\% всієї робочої сили ЄС [16].

Для Європейського Союзу характерною рисою $€$ нерівномірність розподілу трудових мігрантів серед країн ЄС. Найбільш привабливим країнами для трудових мігрантів $\epsilon$ країни Західної та Центральної Європи, порівняно $з$ іншими країнами $€ С$. Частка ключових працівників-іммігрантів майже дорівнює нулю у таких країнах Східної Європи, як Румунія, Болгарія, Польща та Словаччина, тоді як їх частка коливається у діапазоні 5-20\% у таких країнах, як Італія, Бельгія, Німеччина, Швеція та Австрія. Найбільша частка працівниківіммігрантів спостерігається в Ірландії (26\%), Кіпрі (29\%) та Люксембурзі (53\%).

Серед основних причин того, чому трудові мігранти обирають країни Західної та Центральної Європи, як кінцеві пункти трудової міграції, доцільно зазначити економічний аспект (країни $€ \subset$ з більш високим рівням життя пропонують вищу заробітну плату: станом на жовтень 2020 року найвищі мінімальні заробітні плати спостерігалися у Люксембурзі (2,142 євро); Великобританії (1,760 євро); Ірландії (1,707 євро); Нідерландах (1,654 євро) 
та Бельгії (1,594 євро), проте запропоновані вакансії на ринку праці цих країн потребують належної кваліфрікації від трудового мігранта) [17]. Для країн-членів ЄС Східної та ПівденноСхідної Європи основними причинами, що спонукають трудових мігрантів здійснювати свою міграцію до цих країн, $€$ економічний аспект (вищий рівень заробітних плат, порівняно 3 країнами-донорами), територіальний аспект (територіальна близькість країни-донора та країни-реципієнта/країни первинного приймання); соціальний аспект (ментальна, релігійна, культурна, мовна близькість країнидонора та країни-реципієнта).

Удосконалення міграційної політики країни $€ \subset$ має передбачати посилення співпраці 3 сусідніми країнами, зокрема з Україною, Білоруссю та Російською Федерацією. Потрібно відмітити, що Україна разом з Білоруссю та Російською Федерацією формують новий п'ятий міграційний напрям - Східний сухопутний маршрут (Eastern Borders route). Хоча цей напрям легальної та нелегальної міграції до $€ \subset$ не $€$ домінуючим, проте він досить стрімко зростає. Динаміка міграційного руху біженців та осіб без громадянства Східним сухопутний напрямом у 2015-2019 роках наведено на рисунку 1.

Необхідно зазначити, що зростання обсягів міграційних потоків біженців та осіб без громадянства до ЄС Східним сухопутним маршрутом у 2015 році було спричинено перш за все військовими фракторами (військові дії в Україні, втрата повноцінного контролю над державним кордоном на Сході України), неможливістю забезпечити Російською Федерацією, Білоруссю та Україною повноцінного контролю над власними кордонами через їх велику протяжність.

Співпраця країн-членів ЄС та країн проміжної дислокації Східного сухопутного маршруту має ряд особливостей. Співпраця у форматі ЄС-Білорусь у 2020 році майже припинена у зв'язку з загостренням політичної кризи у Білорусі, фрактичною узурпацією влади та ігноруванням Білоруським політичним керівництвом базових європейських цінностей, прав і свобод громадян. Співпраця у форматі $€ С$-Російська Федерація $€$ досить обмеженою у зв'язку з впливом політичного фрактору (фрактична легалізація узурпації влади в РФ), військового фактору (здійснення військової інтервенції РФ на території України, незаконна анексія Кримського півострову). Тому найбільш ефективною $€$ співпраця в рамках Східного сухопутного маршруту між Україною та ЄС. Станом на кінець 2020 року через територію України до ЄС проходять такі міграційні потоки, як: 1. Країни Середньої та Південної Азії - Туреччина - Україна - Польща - Німеччина; 2. Китай - Російська Федерація - Україна - Білорусь - Прибалтійські країни.

Транскордонна співпраця України та $€ \mathrm{C} €$ доволі успішною, проте існують певні загрози, зокрема для $€ \mathrm{C}$, які мають бути превентивно нейтралізовані. Україна $€$ не тільки країноюдонором людських ресурсів, але й країною проміжної дислокації. Окрім того, посилення заходів міграційного контролю $€ С$ та Туреччини на Східносередземноморському мігра-

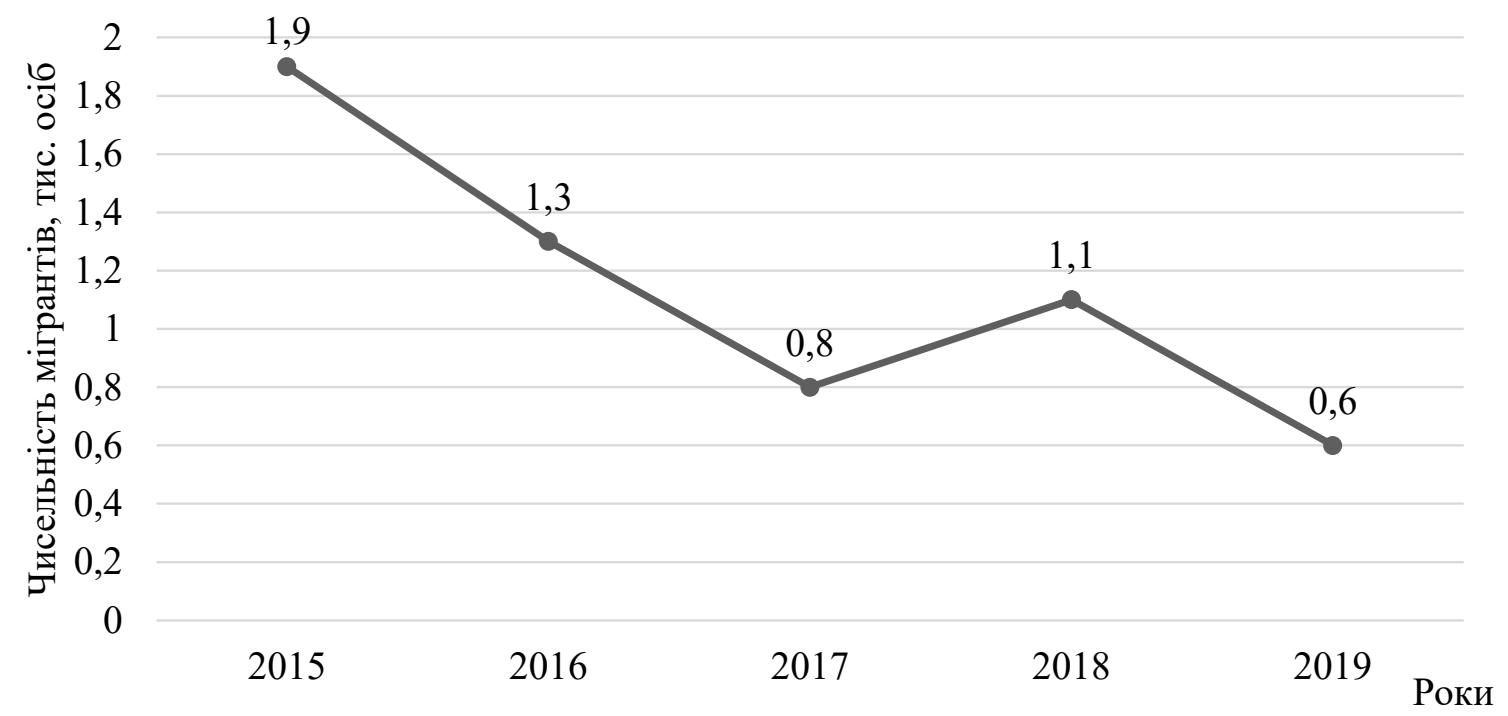

Рис. 1. Інтенсивність міграційних потоків біженців та осіб без громадянства до ЄС Східним сухопутним маршрутом у 2015-2019 роках

Джерело: складено автором за даними [7; 8; 18; 19; 20] 
ційному маршруті призводять до того, що біженці та особи без громадянства шукають нові напрями міграції. Саме такі фрактори, як територіальна близькість України та $€ C$, наявність непідконтрольних зон державного кордону України через військові дії, сприяють перенаправленню частини мігрантів Східносередземноморського міграційного маршруту до України.

Висновки. Міграційна політика $€ C$ не завжди $\epsilon$ превентивно попереджувальною, проте вона оперативно реагує на виклики, які постають перед міграційною системою ЄС. Найбільш кризовим періодом для усієї міграційної системи ЄС був 2015 рік, коли в наслідок загострення військових дій у Сирії, початку військових дій в Україні та загострення економічних проблем у країнах Асррики призвели до неконтрольованого зростання імміграційних потоків до ЄС. Для оперативного вирішення неконтрольованого зростання міграції біженців та осіб без громадянства у $€ C$ було застосовано такі заходи: швидке фрінансове та матеріальне посилення правоохоронних та силових агенцій ЄC (EUROPOL, EASO, EUROSUR, FRONTEX); відновлення прикордонного контролю у країнах Шенгенської зони; посилення боротьби 3 нелегальними перевізниками мігрантів; розгортання мережі центрів прийому біженців та таборів тимчасового притулку; розроблення принципу квотного розподілу мігрантів за визначеними критеріями (чисельність населення, розмір ВВП, чисельність заяв на отримання статусу біженця, показники безробіття), для того, щоб зменшити «міграційне навантаження» на країни $€ C$, що $€$ країнами первинного приймання мігрантів; впровадження стратегії «міграційного щита», яка передбачає посилену співпрацю з країнами проміжної дислокації, розроблення спільних програм контролю кордону, фрінансування центрів прийому біженців та місцевих громад, що найбільше постраждали від транзитної міграції.

Тактика «міграційного щита» для $€ С$ виявилася найбільш успішною. Зокрема успішними $€$ приклади співпраці у ссрері міграції між ЄС та Туреччиною, ЄС та Лівією, ЄС та Марокко. Тому, доцільним $є$ посилення цього напряму співпраці з іншими країнами проміжної дис- локації (Алжир, Туніс, Молдова, Україна) та у довгостроковій перспективі - з країнами-донорами міграційних потоків. Так, для мінімізації нелегальної міграції з Сирії, Іраку та Асрганістану ЄС доцільно створити фонди цільової підтримки розвитку цих держав, але ці фронди мають почати діяти після завершення активних бойових дій. Другим напрямом співпраці $€$ співпраця в межах ЄС-Афррика, а саме 3 країнами-донорами. Для мінімізації міграції за цими напрямами необхідно розширювати програми цільової підтримки малого та середнього бізнесу, підтримки медичного та продовольчого забезпечення для країн-донорів. Окремим викликом для міграційної системи ЄС стали також форс мажорні фактори, зокрема пандемія коронавірусу. Закриття офріційних транзитних сполучень збільшили інтенсивність нелегальних транзитних сполучень та створили додаткове навантаження на органи правоохоронного, міграційного та прикордонного контролю. Окрім того, потребує розширення співпраця ЄС з країнами проміжної дислокації в межах Східного сухопутного маршруту, оскільки посилення міграційного контролю на Східносередземноморському маршруті природно призведе до перерозподілу міграційних потоків до найближчих маршрутів. Додатковим загрозливим фрактором $€$ висока політична нестабільність країн проміжної дислокації в межах Східного сухопутного маршруту. В разі загострення цього фактору, міграційне навантаження посилиться на країни-члени ЄС, що мають спільні кордони $з$ країнами проміжної дислокації, а також безпосередньо на інші країни проміжної дислокації в межах Східного сухопутного маршруту. Основними напрямами співпраці в межах Східного сухопутного маршруту мають стати такі заходи, як якісна модернізація центрів прийому біженців та таборів тимчасового притулку; посилення прикордонної кооперації між країнами ЄС та країнами проміжної дислокації; посилення фрінансової і матеріальної допомоги щодо реформування системи прикордонного контролю у країнах проміжної дислокації з метою забезпечення повноцінного контролю над державними кордонами; активне сприяння закінченню бойових дій в Україні та замороженого конфрлікту у Молдові.

\section{СПИСОК ВИКОРИСТАНИХ ДЖЕРЕЛ:}

1. Migration and migrant population statistics - Statistics Explained (2020) Eurostat. URL: https://ec.europa.eu/ eurostat/statistics-explained/index.php/Migration_and_migrant_population_statistics\#Migrant_population:_21.8_ million_non-EU-27_citizens_living_in_the_EU-27_on_1_January_2019 
2. Conti, N., Di Mauro, D., \& Memoli, V. (2019) Citizens, immigration and the EU as a shield. European Union Politics, 20(3), 492-510. https://doi.org/10.1177/1465116519834648

3. Van Wolleghem, P.G. (2019) Where is the EU's Migrant Integration Policy Heading? International Review of Public Policy, 1(2), 218-237. https://doi.org/10.4000/irpp.396

4. Estevens, J. (2018) Migration crisis in the EU: developing a framework for analysis of national security and defence strategies. Comparative Migration Studies, 6(1), 1-21. https://doi.org/10.1186/s40878-018-0093-3

5. Shubham P. (2016) European Migrant Crisis: Financial Burden or Economic Opportunity? Social Impact Research Experience (SIRE). 43. URL: http://repository.upenn.edu/sire/43

6. Statista (2020, May 18) Number of illegal entries at borders of the European Union 2009-2019. URL: https://www.statista.com/statistics/454775/number-of-illegal-entries-between-bcps-to-the-eu/

7. Database - Eurostat (2020) Eurostat. URL: https://ec.europa.eu/eurostat/data/database

8. Frontex / European Union Agency (2020) Frontex. URL: https://frontex.europa.eu/

9. EU migration policy (2020, December 14) European Council. URL: https://www.consilium.europa.eu/en/ policies/migratory-pressures/\#

10. United Nations High Commissioner for Refugees (2020) UNHCR - The UN Refugee Agency. UNHCR, The UN Refugee Agency. URL: https://www.unhcr.org/

11. Irregular border crossing on the West African Route (2016, March 2) Open Migration. URL: https://openmigration.org/en/infographic/irregular-border-crossing-on-the-west-african-route/

12. MacGregor, M. (2019, June 11) Spain's Canary Islands - still a magnet for migrants. InfoMigrants. URL: https://www.infomigrants.net/en/post/17342/spain-s-canary-islands-still-a-magnet-for-migrants

13. Frontex (2019, December) Frontex in brief. URL: https://frontex.europa.eu/assets/Publications/General/ frontex_inbrief_website_002.pdf

14. Western African Route: Migration to the Canary Islands - Irregular Migration Towards Europe, January November 2020 (18 November 2020) - World (2020, November 23) ReliefWeb. URL: https://reliefweb.int/report/ world/western-african-route-migration-canary-islands-irregular-migration-towards-europe

15. Euronews (2020, November 25) How the Canary Islands became Europe's latest migrant hotbed. URL: https://www.euronews.com/2020/11/25/how-the-canary-islands-became-europe-s-latest-migrant-hotbed

16. Fair employment conditions for migrant workers in the EU - How to provide better support services for migrants? (2020, October 9) ILO. URL: https://www.ilo.org/budapest/whats-new/WCMS_757579/lang--de/index.htm

17. Statutory minimum wages (2020) Eurofound. URL: https://www.eurofound.europa.eu/data/statutory-minimum-wages

18. Ministère de l'Europe et des Affaires étrangères (2020) Ministère de l'Europe et Des Affaires. URL: https://www.diplomatie.gouv.fr/ru/

19. Deutsche Welle (www.dw.com) (2020) Ankara, Athens use refugees in dangerous political game. DW.COM. URL: https://www.dw.com/en/ankara-athens-exploit-refugees-in-dangerous-political-game/a-52654716

20. Eastern Borders Route (2020) Frontex. URL: https://frontex.europa.eu/along-eu-borders/migratory-routes/ eastern-borders-route/ 